\title{
A literature review of the current consideration of animals in China
}

Courtney Henry, Vincent Yau-Shun Chow and Nadine Grinberg 


\section{Contents}

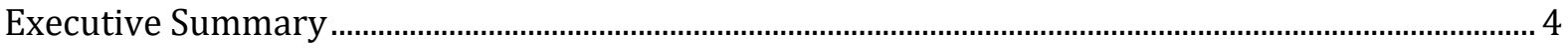

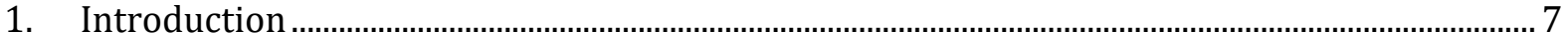

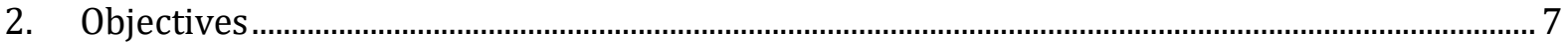

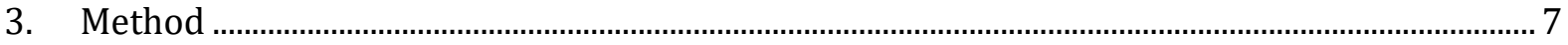

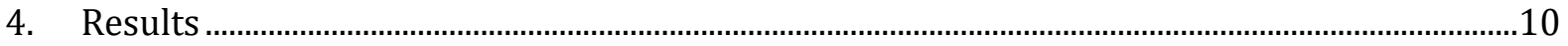

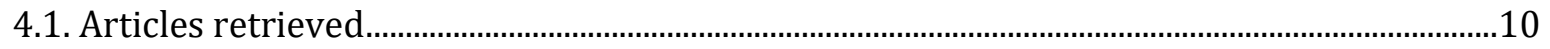

4.2. The consideration of nonhuman animals in general ..................................................................11

4.2.1. Current attitudes towards the moral consideration of animals ..........................................11

4.2.2. Appeals to philosophical traditions to promote the moral consideration of animals..13

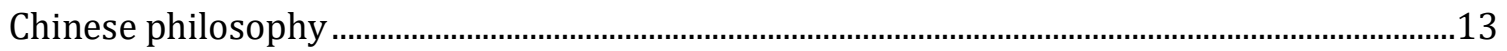

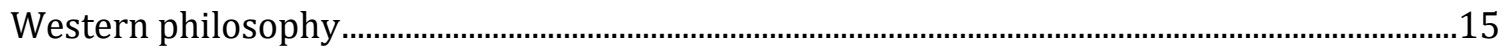

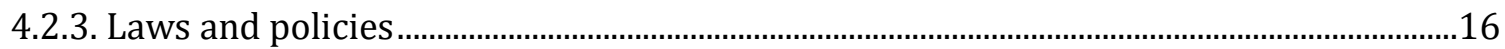

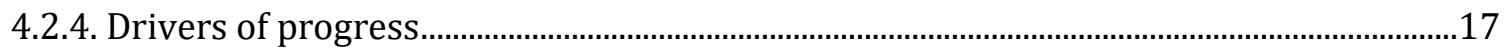

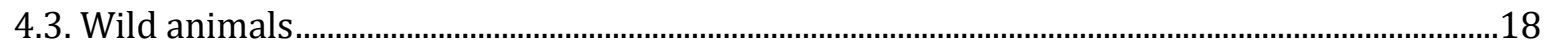

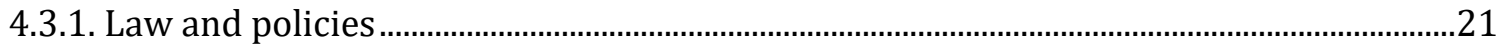

4.3.2. Conflation of conservation and wild animal protection ......................................................22

4.3.3. Public attitudes towards wild animals....................................................................................

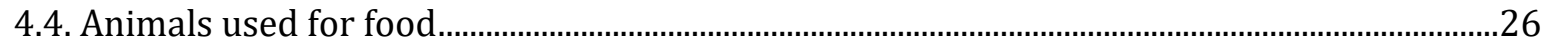

4.4.1. Potential initiatives for improving the situation of animals used for food .......................26

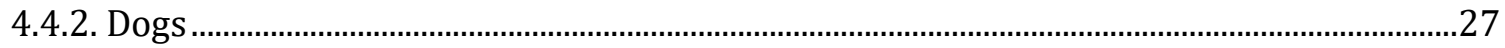

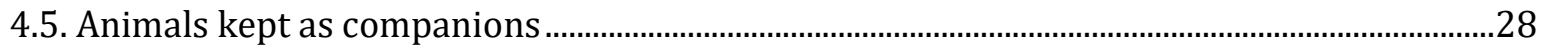

4.5.1. Economic growth and increase in keeping animals as companions...................................28

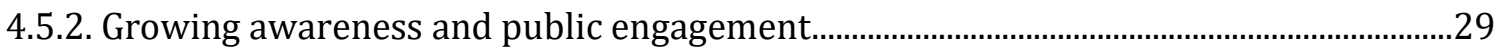

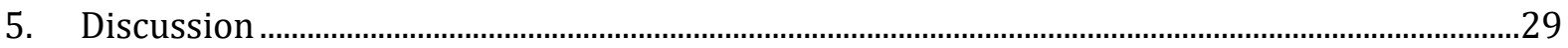

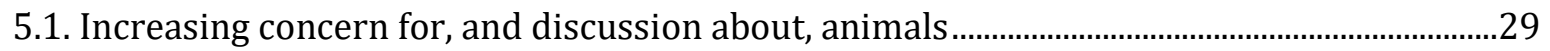

5.2. Tapping into Chinese philosophical traditions …………………………......................................30

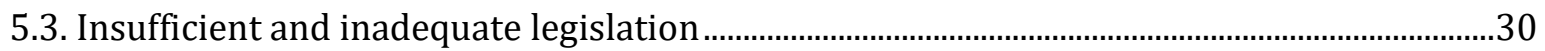

5.4. Wild animals still not recognized as individuals ..........................................................................

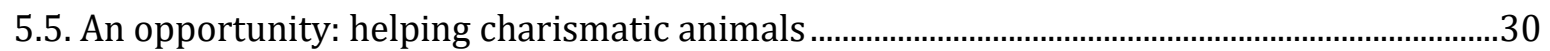

5.6. Foundation-building through public education ..............................................................................31 
5.7. General takeaways from the situation of animals used for food . .31

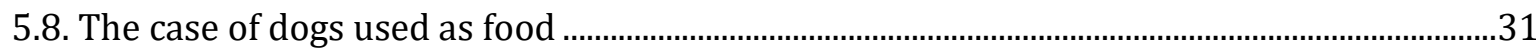

5.9. Takeaways from the situation of animals kept as companions ................................................32

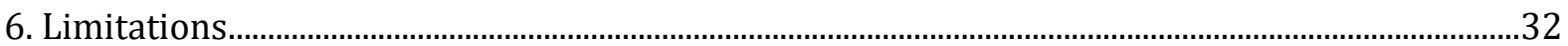

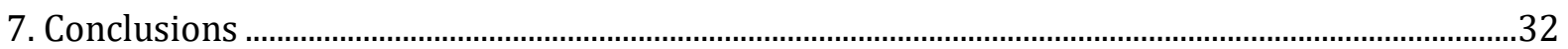

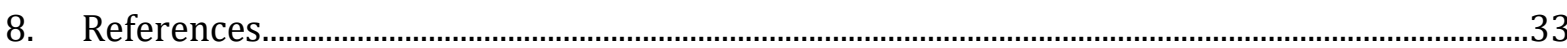




\section{Executive Summary}

\section{Background}

China is the world's most populous country and a growing economic and political power. The country has a vast wild animal population, and is among the largest users of animals around the world. However, animal advocacy is still in its early stages of development in the country. China's approach and attitudes towards the moral consideration and legal protection of nonhuman animals are increasingly important, both domestically and internationally. Therefore, it is important that animal advocates globally understand Chinese attitudes towards animals and research ways to incorporate concern for wild animal suffering in the country's nascent animal advocacy movement.

\section{Objectives}

Explore the situation of animals in China to help promote animal advocacy in the country, and the lessons that animal advocates should learn in order to more effectively help wild animals in particular.

\section{Methodology}

We sought to answer these questions through a review of both Chinese and English academic literature.

\section{Results}

The main topics identified in the literature review include public attitudes, law and policy, and education. The literature includes discussion of both the current situation of animals in China as well as perspectives on how the situation might be improved. Some of the literature deals with animals in general, while another part of it refers to animals used for food (including dogs), animals kept as companions, as well as animals living in the wild. We did not find literature addressing the issue of wild animal suffering, although some literature examines related issues.

The literature review shows a significant increase in the literature with respect to the consideration of animals in China, reflecting a growing concern within Chinese society about the moral consideration of animals. It also reveals a nascent academic debate between defenders and critics of speciesist ideas. As for legislation and policy, the literature often compares Chinese laws and regulations with those in Europe and North America. Moreover, the review indicates that there are limited Chinese laws protecting animals, which are often not effectively enforced. This seems partly due to the lack of influence by people interested in the moral consideration of animals in China.

Nonetheless, there seems to have been changes to the status quo in recent years, partly due to changing demographics as well as external influence. The Chinese public seems increasingly receptive to animal advocacy campaigns, especially young people, highly educated people, and those living with animals as companions. This is demonstrated by public attitudes towards 
different types of animals, whether it be animals in general, animals used for food, or animals kept as companions. The literature indicates a need to localize animal-related concepts and ideas for China to make further progress, using arguments taken from Confucianism, Taoism and Buddhism, for example.

In the case of wild animal suffering, the literature does not indicate any awareness of this cause area as yet. The literature on wild animals focus for the most part on conservation. In these articles, there is a common confusion between species conservation and the protection of wild animals. Animals are typically not identified as individuals with a wellbeing, except for some animals considered charismatic in China, such as pandas.

Finally, the study of the literature about animals used for food, including dogs, and animals kept as companions confirms some of the results obtained from the literature about the consideration of animals in general.

\section{Discussion}

The growth of the discussion in the literature surrounding the moral consideration of animals in China is a positive indicator for growing interest in animals over time. However, this increase may be partly due to significant growth in the number of animals used as resources for different purposes in China, especially in factory farms. There seems to be potential for concern for animals to continue to grow, as the changing attitudes among young and educated people show. In addition, the relative success of education efforts in other fields, such as conservation, indicates that education may also work to achieve a different purpose, such as a higher concern for the welfare of nonhuman animals in general and wild animal suffering in particular.

The limitations in Chinese animal protection laws and policies indicates that there is still much work to do before the animals in China are adequately protected by the law. They also indicate that segments of the population interested in animal protection are still too weak to have an influence on policy-making. However, China is not unique in this regard, as other countries also have insufficient and inadequate animal protection legislation.

Perhaps most significantly, the defence of wild animals faces the problem of the common conflation of the protection of wild animals as individuals with interests of their own, and the conservation of their species. This happens also in other countries, although it is more problematic in China as there is no discussion yet of wild animal suffering. However, the case of animals regarded as charismatic may provide an opportunity to introduce the concept of wild animal suffering among the Chinese public and authorities, as well as methods to research the welfare of animals living in the wild.

\section{Limitations}

Some of the main problems facing animal advocates in China are not addressed in the literature. These include the ways organizations can best approach their work in China, what their relationship with Chinese authorities should be, how animal advocacy is developing in China, and the ways in which concern for wild animals may be best advocated for in China. 


\section{Conclusions}

- While concern for animals in Chinese society has grown, it is still insufficient to achieve a significant change in the current situation.

- Animal protection legislation in China is less developed than in other major countries.

- Building the social basis necessary for the successful defence of animals in China appears feasible through education.

- China's own philosophical traditions could provide the grounding for arguments in support of the moral consideration of animals used to promote such a change.

- There is as yet no concern about wild animals as individuals, so their protection is confused with the conservation of their species, similar to other countries.

- Interventions to reduce wild animal suffering among charismatic animals in China may be a promising way to grow concern about wild animals as individuals.

Other questions remain to be explored using different methods, like interviews to key agents in the field, such as scholars and animal advocates. 


\section{Introduction}

China is the world's most populous country and second largest economy. It is also the world's fourth largest country in the world by area. Even if a large part of it is desert, this means many wild animals live there. In addition, the use of animals for food and other purposes in China is one of the most significant worldwide. Politically, China is immensely powerful and, as a significant investor in many countries, it has a growing influence on world affairs. Consequently, the views towards nonhuman animals in China will affect a vast number of animals, both within and without the country. This makes the evolution of attitudes towards animals in China a very important issue for those concerned about the moral consideration of all sentient beings.

For animal advocacy to achieve its goals, not just in the near-term but in the long-term, it needs to be a more significant force in China than it is now. Foreign animal advocates have limited knowledge of how best to carry out activism in China. This could lead to mistakes and inefficient use of resources. Moreover, mistakes made in the short-term could result in animal advocacy being stunted in the long-term in China, for example by antagonizing the Chinese public or authorities. It is therefore important to learn more about how best to conduct advocacy activities in China before beginning to carry out or support such activism.

\section{Objectives}

The study aims to begin to answer the following questions:

1. What lessons can animal advocates learn from the consideration of animals in China, which would better inform their efforts to effectively help animals in China?

2. What lessons can animal advocates learn that would better inform their efforts to effectively help wild animals in particular?

In order to do this, this study aims to provide relevant information regarding the current moral and legal consideration given to animals in China, the ways in which such consideration may be changing, and insights surrounding how they might be improved.

\section{Method}

The methodology used to explore these questions consisted of a semi-systematic review of both the Chinese and English literature relevant to the animal advocacy movement in China, with an emphasis on literature pertaining to wild animals. This work is novel as, to our knowledge, there are no known reviews of the literature surrounding animal protection activities in China. There have been overviews written about China's animal advocacy movement (Li \& Davey, 2013), as well as highly informative research about China's legal, social and cultural landscapes as they relate to animals (Cao, 2015), but there has not been a systematic review of the literature available, as far as we are aware. 
To conduct this literature review, we devised dozens of search terms relating to animal protection in China (Table 1), including appropriate synonyms, and used them to retrieve articles on several major databases. The English databases searched were Agricola, BIOSIS, CAB Abstractions, Proquest, Scopus, Web of Science and Wiley Online Library. The Chinese database searched was the China National Knowledge Infrastructure (CNKI) database (中国知网). We limited our search to articles published from 1 January 1980 to 2 July 2019. In total, 507 Chinese articles (Table 1 ) and 177 English articles (Table 2) were retrieved after removing duplicates and sorting for relevance.

Table 1. Chinese search terms and articles retrieved

\begin{tabular}{ccc} 
Database & Search Terms & Number \\
1 January $1980-$ & of \\
2 July 2019 & China AND animal AND advocacy & Articles \\
\hline
\end{tabular}

CNKI (China

ti(中国 AND 我国 AND 中华)

National

Knowledge

Infrastructure)

AND ti (动物 OR 野生 OR 熊猫 OR 老虎 OR 狗 OR 猫 OR 猪 $\mathrm{OR}$ 鸡 $\mathrm{OR}$ 牛 OR 家畜 OR 牲畜 OR 野兽 OR 熊 OR 大象 OR 藏羚羊 OR 犘牛 OR 豹子 OR 貂 OR 儒艮 OR 帕拉斯猫 OR 熊狸 OR 狝 OR 梅花鹿 OR 马鹿 OR 鸟它乌 OR 美洲鸟 OR 尼羅 鱞 OR 亚洲巨龟 OR 暹罗鳄 $O R$ 咸水鳄 $O R$ 虎紋蛙 OR 田雞)

$A N D$ ti (倡导 $\mathrm{OR}$ 行动 $\mathrm{OR}$ 主义 $\mathrm{OR}$ 解放 $\mathrm{OR}$ 救助 $\mathrm{OR}$ 福利 $\mathrm{OR}$ 非营 OR 利性 OR 营利 OR 组织 OR 机构 OR 慈善 OR 政府 OR 保护 OR 游说 OR 政策 OR 法律 OR 立法 OR 权利 OR 运 动 $O R$ 人道 $O R$ 对待 $O R$ 保育 $O R$ 残酷 $O R$ 素食 $O R$ 纯素 $O R$ 实验 $O R$ 试验 $O R$ 社会 $O R$ 动物法 $O R$ 全国人 $O R$ 代表 $O R$ 常 委 $O R$ 常务 $O R$ 委员 $O R$ 濒危 $O R$ 植物 $O R$ 贸易 $O R$ 公约 $O R$ 华盛顿 OR 濒临 OR 绝种 OR 动植 OR 林业 OR 局 OR 繁育 OR 名录)

Screened for

relevance minus

duplicates 
Table 2. English search terms and articles retrieved

\begin{tabular}{|c|c|c|}
\hline $\begin{array}{c}\text { Database } \\
1 \text { January } 1980- \\
2 \text { July } 2019\end{array}$ & $\begin{array}{c}\text { Search Terms } \\
\text { China AND animal AND advocacy }\end{array}$ & $\begin{array}{l}\text { Number } \\
\text { of } \\
\text { Articles }\end{array}$ \\
\hline & ti(China OR Chinese) & \\
\hline Agricola & & 32 \\
\hline BIOSIS & $\begin{array}{l}\text { AND ti(Animal OR "non-human" OR nonhuman OR wildlife } \\
\text { OR "wild-life" OR bear OR dog OR cat OR pig OR chicken OR } \\
\text { cow OR "companion animal" OR "wild animal" OR panda }\end{array}$ & 78 \\
\hline CAB Abstracts & $\begin{array}{l}\text { OR elephant OR tiger OR "Tibetan antelope" OR rhinoceros } \\
\text { OR leopard OR sable OR dugong OR "Pallas cat" OR }\end{array}$ & 84 \\
\hline Proquest & $\begin{array}{l}\text { Leopard OR Binturong OR Macaque OR "sika deer" OR "red } \\
\text { deer" OR ostrich OR rhea OR "giant Asian pond turtle" OR }\end{array}$ & 356 \\
\hline Scopus & $\begin{array}{l}\text { "Nile crocodile" OR "saltwater crocodile" OR "Siamese } \\
\text { crocodile" OR "Indian bullfrog") }\end{array}$ & 185 \\
\hline Web of Science & & 193 \\
\hline $\begin{array}{l}\text { Wiley Online } \\
\text { Library }\end{array}$ & $\begin{array}{l}\text { AND ti(advocacy OR advocate OR activis* OR liberation OR } \\
\text { rescue OR welfare OR not-for-profit OR nonprofit OR "non- } \\
\text { profit" OR charit* OR NGO OR "non-governmental } \\
\text { organi?ation" OR CWPL OR "Wildlife Protection Law" OR } \\
\text { lobby OR polic* OR law* OR legislat* OR rights OR "rights } \\
\text { movement" OR protection OR "ethical treatment" OR } \\
\text { conservation OR cruelty OR vegetarian* OR vegan* OR } \\
\text { experiment* OR "laboratory testing" OR "social movement" } \\
\text { OR "Wildlife law" OR "Wildlife legislation" OR "Wildlife } \\
\text { protection legislation" OR WPL OR "Standing Committee of } \\
\text { the National People's Congress" OR "National People's } \\
\text { Congress" OR SCNPC OR NPC OR "Standing Commitee" OR } \\
\text { "Convention on International Trade in Endangered Species } \\
\text { of Wild Fauna and Flora" OR "International Trade in } \\
\text { Endangered Species of Wild Fauna and Flora" OR CITES OR } \\
\text { "Convention on International Trade in Endangered } \\
\text { Species" OR "State Forestry Administration" OR "National } \\
\text { Forestry and Grassland Administration" OR "State Forestry } \\
\text { and Grassland Administration" OR "Forestry and Grassland } \\
\text { Administration" OR "State administration of forestry and } \\
\text { grassland" OR NFGA OR SFGA OR FGA OR "List of Terrestial } \\
\text { Wildlife under Special State Protection for Captive } \\
\text { Breeding" OR "Captive Breeding Wildlife List") }\end{array}$ & 30 \\
\hline
\end{tabular}

Screened for

relevance minus

duplicates 


\section{Results}

\subsection{Articles retrieved}

The results indicate a growing interest over time in the literature with respect to animals in China. In the Chinese literature, only 11 articles were published in 1980-1989, compared to 292 articles in 2010-2019. In the English literature, only 6 articles were published in 1980-1989, compared to 91 articles in 2010-2019 (these are total results, including articles relating to animals used for food and their legal protection or lack thereof). There have also been corresponding increases in the literature surrounding wild animals in particular (Figure 1).

Around half of both the retrieved Chinese (50\%) and English (52\%) articles related to wild animals (Table 3 and Table 4). However, a significant proportion related to animals used for food. Very few articles related to fur (3) or laboratory experimentation (3), but that was likely due to the search terms used, which were not devised to retrieve articles addressing these topics. The skew of the retrieved articles towards wild animals was expected given the search terms used, which reflected our project's emphasis on wild animals.

\section{Figure 1. Chinese articles published in 1980-2019}

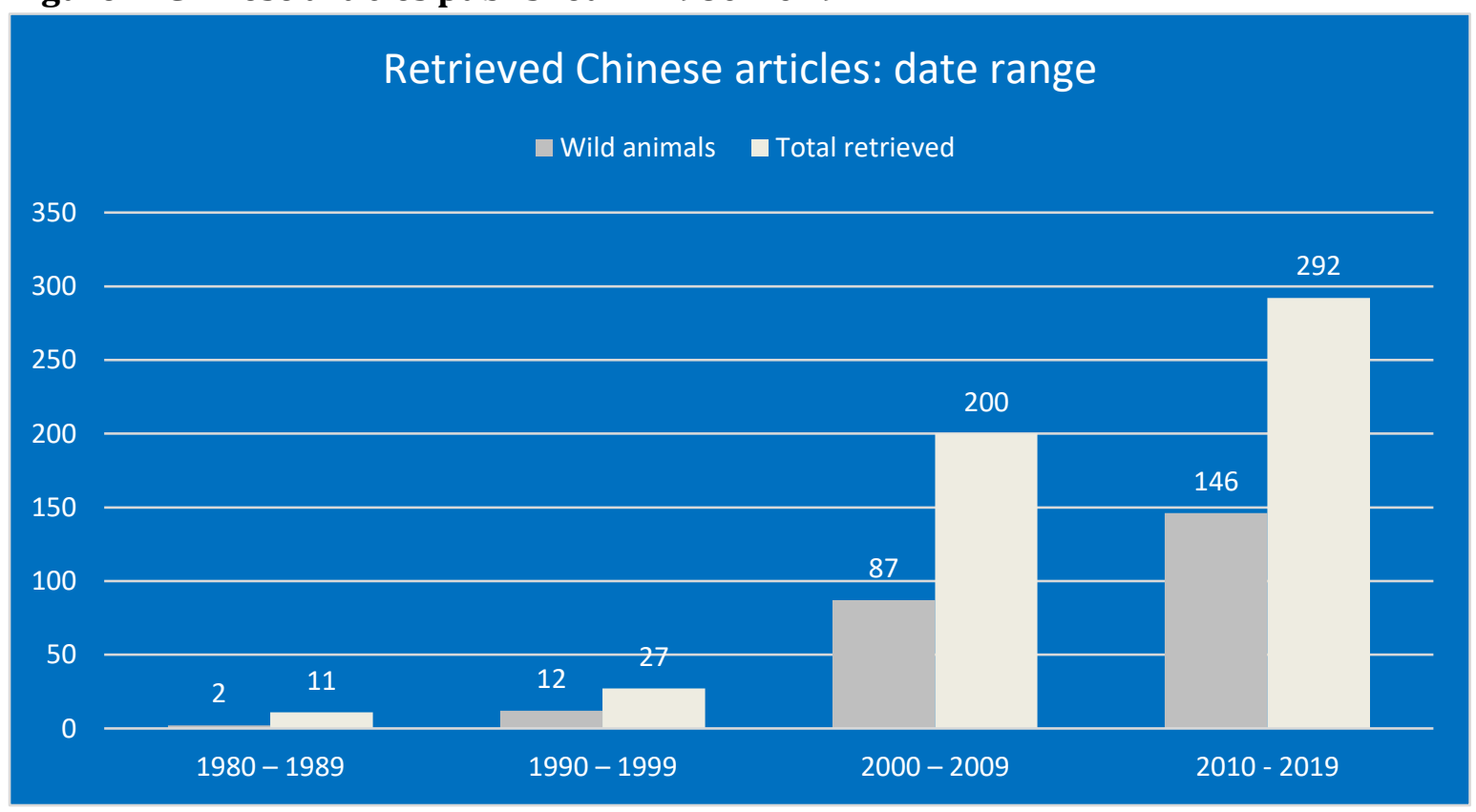

Table 3. Chinese articles by sub-category

\section{Sub-category}

Wild animals

Animals used for food

Animals kept as

Companions

\section{Number of articles}

247

208

22 
Animals used in laboratories

52

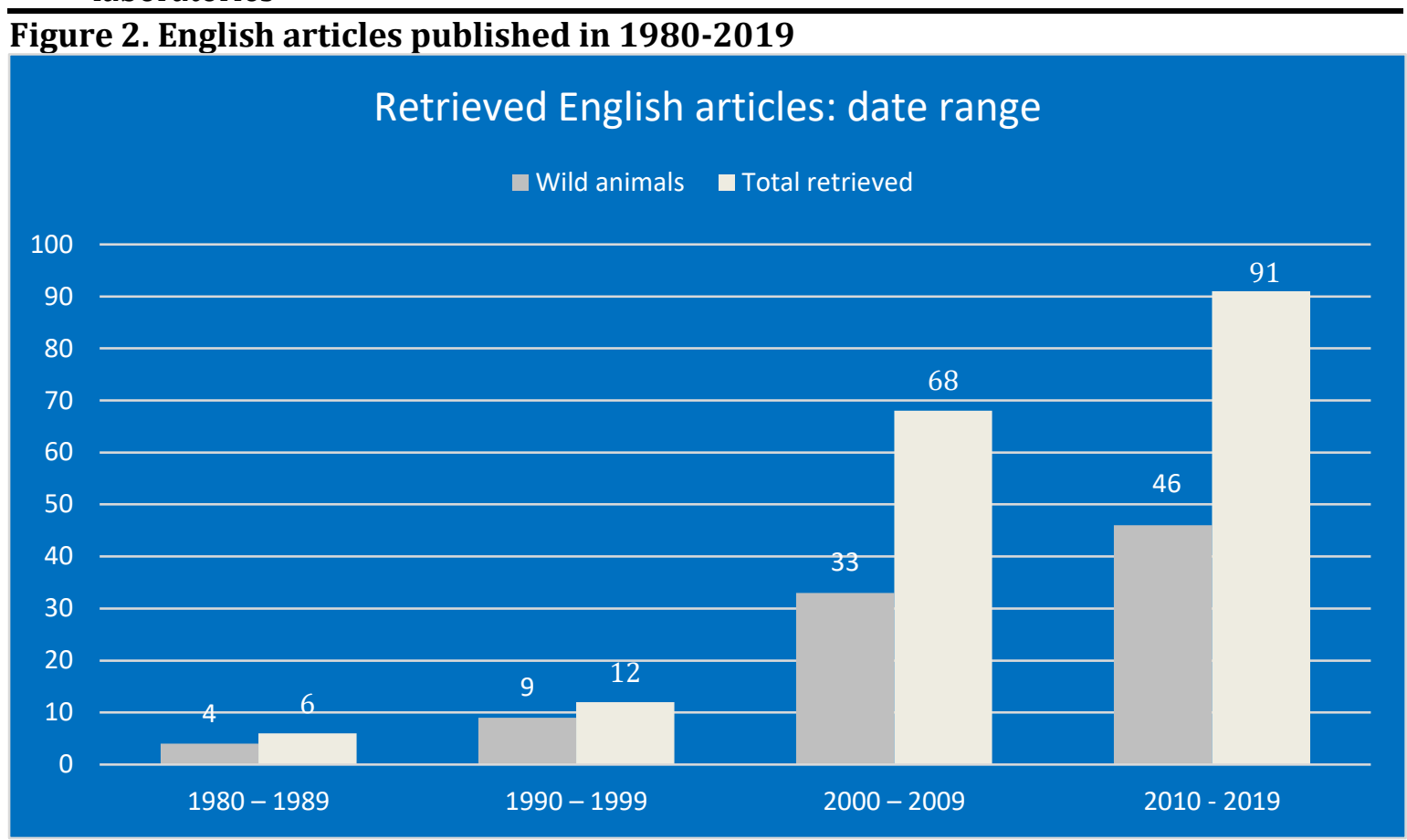

Table 4. English articles by sub-category

\begin{tabular}{cc}
\hline Sub-category & Number of articles \\
\hline Wild animals & 92 \\
$\begin{array}{c}\text { Animals used for } \\
\text { food }\end{array}$ & 25 \\
$\begin{array}{c}\text { Animals kept as } \\
\text { companions } \\
\text { Other }\end{array}$ & 18 \\
\hline
\end{tabular}

\subsection{The consideration of nonhuman animals in general}

\subsubsection{Current attitudes towards the moral consideration of animals}

Whereas most of the retrieved English articles could be summarized, this was not possible for the Chinese articles given that significantly more Chinese articles than English articles were retrieved. Therefore, for the Chinese articles, summaries of a few of the most relevant and interesting articles are provided below. 


\section{Chinese articles}

Overall, the main concerns of the Chinese literature were speciesism and the moral consideration of nonhuman animals in relation to humans. The debate over these issues mirrors similar arguments that have played out over recent decades in Europe and North America, such as the clash between speciesist and nonspeciesist views, arguments surrounding the legal status of animals, and more.

Chen \& Zhou (2002) defended a speciesist viewpoint in response to Yan Chunyou, a philosophy professor at Beijing Normal University, who argues that "humans are not superior to animals from the perspective of nature. In nature's banquet, everything that exists is equal." (Chen \& Zhou, 2002, p.64) The authors asked whether effective animal protection requires changing the moral status of animals through "personification" and treating animals as "legal subjects" - entities capable of holding

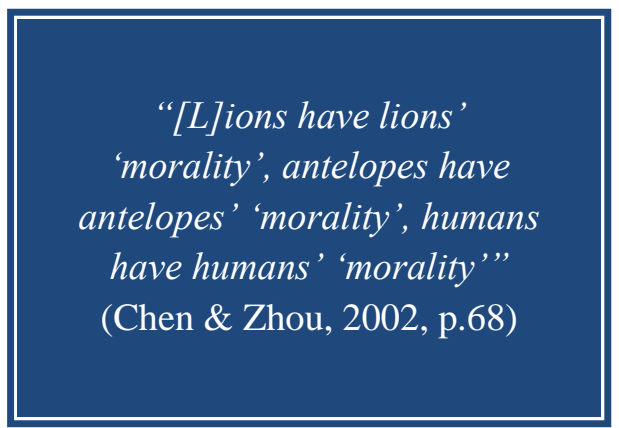
rights and duties - rather than mere "legal objects" - entities over which a legal subject may hold rights. The authors also referred to relevant provisions of the German Civil Code, specifically Section 90a, which says that "animals are not things," thereby elevating animals from being the objects of rights to being the subject of rights.

The authors concluded that animals cannot be deemed legal subjects because of their lack of rationality and our inability to form moral communities with them. Wild animals have their own moralities:

"Nature has its own rules, which can also be called 'morality' when considering it from a human perspective. In this way, lions have lions' 'morality', antelopes have antelopes' 'morality', humans have humans' 'morality'." (Ibid., p.68)

Rejecting speciesism is a form of "anthropomorphizing" nonhuman animals, in their view. Nonetheless, the authors stressed that disagreement with nonspeciesism does not mean that they are opposed to granting legal protection to animals. Guo \& Li (2009) echoed this speciesist view, arguing that protecting animals does not necessarily mean giving them legal subject status, as animals can only be objects of legal relations.

\section{English articles}

The English literature mainly featured studies exploring current attitudes in China towards animals generally through polls. These studies indicated differences in attitudes across various demographics, suggesting that pro-animal attitudes are more prevalent among students, young people, and college-educated people. In particular, those with experience living with or keeping animals as companions were more likely to demonstrate awareness of key animal concepts.

Two studies indicated that Chinese respondents had low awareness and understanding of the concept of animal welfare applied to animals kept in farms. In one study involving 229 respondents, $80.3 \%$ knew nothing or very little about the concept (Zhao \& Wu, 2011). In another 
study involving 6006 questionnaires, ${ }^{1}$ two-thirds of respondents had never heard of the concept despite being young and highly educated (You et al., 2014).

Another study involving 2,111 respondents indicated that college students from developed regions had a better understanding of animal welfare (of laboratory animals, wild animals and animals used for entertainment) than students from developing or underdeveloped regions. The study also found that higher proportions of students generally agreed that farming practices such as battery cages and inhumane slaughter are cruel, compared with other demographics (Yin et al., 2018).

Two studies found that awareness of animal welfare is influenced by past experiences with animals kept as companions. For example, undergraduates who have lived with animals as companions were more familiar with the wellbeing and suffering of animals (Yin et al., 2018), while respondents who had kept animals as companions had greater awareness of animal protection (Su \& Martens, 2018).

Chinese respondents' moral attitudes towards nonhuman animals were also explored. According to one study, moral absolutists (low relativism) displayed the most positive attitudes towards animals, whereas moral subjectivists (high relativism) displayed the least positive attitudes (Ibid.).

\subsubsection{Appeals to philosophical traditions to promote the moral consideration of animals}

\section{Chinese philosophy}

\section{Chinese articles}

The Chinese literature mainly featured arguments in favor of promoting pro-animal ideas in China through local philosophical traditions. Articles often discuss the limitations of ideas imported from abroad, while also posing the question of why local ethical resources are not being tapped given some of their similarities with foreign ethical ideas relating to animals.

One article urged the government to raise people's awareness of traditional ideas relevant to the protection of wild animals in order to better protect wild animals today (Ceng, 2017). The thinking is that protecting wild animals requires "ethical ideas that can be accepted by the general public" (Ibid., p.143). Two philosophical traditions are potentially helpful for improving people's attitudes and behavior towards wild animals -Confucianism and Taoism - both of which purportedly support the idea of "harmony" between man and nature, thereby implicitly supporting strong wildlife protection (note that the author assumed that wild animals are part and parcel of nature).

\footnotetext{
${ }^{1}$ The sample in You et al. (2014) was said to be 6,006 "effective questionnaires" (p.2), while subsequent paragraphs mentioned various different numbers of respondents: 5,982, 5,705, 5,772, and 5,976
} 
Another article also explored the potential of Confucianism and Taoism for improving animal protection in China, emphasizing that most theoretical advancements of contemporary animal protection lack adaptability to Chinese society because they are introduced from abroad (Min \& Gao, 2014). Therefore, there is a need to draw wisdom from traditional Chinese culture in order to construct "localized theory," using, for example, Taoist ideas that have similarities with concepts in "Western" natural law (Ibid., p.174).

However, Taoism has not been a strong force in Chinese society and culture for a long time, therefore it does not provide a "fundamental impetus" for animal protection ideas in Chinese society (Ibid.). Meanwhile, Confucianism prioritizes humans above other beings, even if it does promote sympathy for all beings that experience suffering. For example, Confucianism purportedly supports animal sacrifice if done to satisfy human needs: "In this way, the Confucian position on animals can be classified as anthropocentrism.” (Ibid., p.173)

\section{English articles}

Confucianism and Taoism are also discussed in the English literature, along with another popular local philosophical tradition: Buddhism. Given that the "Western" model of moral individualism² can seem "unnatural" to Chinese people, who prefer instead a more "tactile pragmatism," promotion of animal protection in China likely requires the development of indigenous forms of animal theory (Kerr \& Dan, 2015, p.74). For example, Confucius advocated for a "protosustainability ethic" (a soft form of humanism), which is very intuitive to people from the "West" while also being a local theory (Ibid., p. 73).

Two articles discuss differences in the opinions of prominent Chinese thinkers and academics. Both articles mention the views of Qiu Renzhong, a highly respected Chinese bioethicist, who has previously proposed "a gradualist approach to animal liberation through steady improvement of animal welfare, animal protection education, law enforcement" (Brown, 2018, p.197). On the other hand, Zhao Nanyuan, a professor at Tsinghua University and the "most strident opponent of an animal welfare movement in China," is strongly against pro-animal policies because they are "anti-human" (Kerr \& Dan, 2015 p.75).

\footnotetext{
${ }^{2}$ Examples of the Western model of moral individualism include Peter Singer's utilitarian ethic and Tom Regan's rights approach, which "obliges humans to respect legal protections for animals that are correlative to their capacities for sentience or selfhood" (Kerr \& Dan, 2015, p.74)
} 


\section{Western philosophy}

\section{Chinese articles}

Discussion of Western philosophy in the Chinese literature mainly occurred in the context of discussions surrounding the importation of "foreign" animal concepts into China. Again, the articles often focused on the need to have more localized theories in order to promote pro-animal attitudes in China. Note that the use of the term "Western" here reflects the use of the term by the

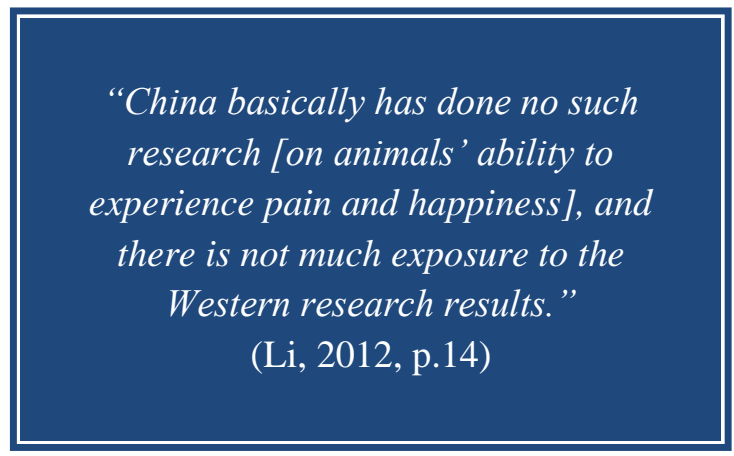
authors themselves.

Animal protection ideas originating in the West have had far-reaching impact on academia and society in China (Li, 2012). Several key texts were cited as particularly influential, including Peter Singer's Animal Liberation (1975). However, there are areas where animal-related research in the West has not penetrated Chinese society to the same extent as it has in the West, such as research into animals' ability to experience pain and happiness: "China basically has done no such research, and there is not much exposure to the Western research results." (Ibid., p.14)

The author called for more attention to be paid in China to animal-related scientific advances in other major countries. However, a greater exploration of "traditional animal ethical resources" is also needed, with the three philosophical traditions cited as examples again: Confucian benevolence, Taoism's ethical value of life, and Buddhism's ideology of equality of all beings.

“These not only conform to China's national psychology but also contain rich animal protection ideas... Our animal protection ethics should not blindly move closer to the West. We need to consider not only protecting animals, but also the development rights of relevant industries." (Ibid.)

Again, the similarities of Chinese and foreign philosophical traditions were emphasized in support of such arguments that local ethical resources should be given more attention. For example, Western animal liberation theory and Chinese Buddhist theory have similar views on the worth of human and animal lives, given that both share non-anthropocentric foundations (Cao \& Chen, 2009). Buddhism's concept of protecting all lives includes nonhuman animals, which can be compared with animal liberation theory's core tenet that all

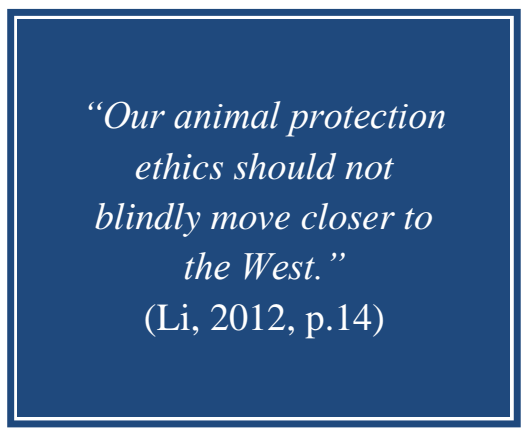
living beings have a right to life (Ibid., p.6). 


\subsubsection{Laws and policies}

\section{Chinese articles}

Articles discussing China's animal protection laws and policies had the highest occurrence in the Chinese literature. Most of these focused on the absence of strong animal protection legislation in the country as well as the insufficiency of existing legislation for effectively protecting animals.

Two articles from 2006 discuss the absence of national legislation criminalizing animal cruelty in China, including cruelty perpetrated against wild animals. China should accelerate efforts to enact such legislation (Ning \& Wang, 2006), especially as the growth of the internet has facilitated the publicization of high-profile cases of animal abuse as well as amplified netizens' outrage (Xu et al., 2006).

A decade later, such legislation was (and is) still missing, while incidents of animal abuse in Chinese society have seemingly increased (Yu, 2015). This and other articles analyze the history and development of foreign animal protection legislation. For example, the United Kingdom's animal welfare laws and policies are described as "some of the earliest and most complete" in this area (Zhao \& Nie, 2007, p.158). A case study of the UK, in addition to New Zealand, Switzerland and others (Xiang, 2009) is also referenced in discussions surrounding how China should define "abuse" in its potential animal cruelty legislation.

Analysis of the laws and policies of other countries, typically to generate lessons in support of China's own policy-making efforts, is a common theme in the Chinese literature on animal laws and policies (see Section 4.3.2).

\section{English articles}

The English literature also focused on the lack of animal protection legislation in China and the inadequacy of existing laws. The English articles were more descriptive in nature, providing readers an overview of the main animal-related laws and policies in China.

China's Constitution (Article 9) stipulates that rare animals and plants should be "rationally used," while the PRC Criminal Law (Article 276) protects animals as much as any other property such as machinery and equipment. Beyond these, there is a lack of major animal protection provisions in China's laws and regulations. In the past, the Provisional Regulations Concerning the Slaughter Tax (屠宰税暂行条例) (now repealed) protected animals somewhat. ${ }^{3}$ However, it contained a loophole whereby the treatment of animals could be based on "the living habits of the people of the various localities" (Tao, 2003, p.351).

The lack of animal protection legislation, as well as the general public's ignorance of nonhuman animal sentience, demonstrate the "poor state of animal welfare in China" (Brown, 2018, p.205). Although the government has ramped up efforts in recent years to encourage pro-animal lifestyle

\footnotetext{
3 "The Provisional Regulations Concerning the Slaughter Tax protected "draught animals, transport animal, breeding stock, milking stock, pregnant animals and young livestock" (Tao, 2003, p. 351)
} 
choices, these efforts have not extended to the legislative arena, meaning that the few animal welfare laws that exist are vague and without "operationalized welfare requirements" (Øyen, 2012, p.580).

Five articles discuss the lack of enforcement of existing laws. Several examples are given, including past failures to control rabies, which led to killing of non-vaccinated dogs (Brown, 2018); and failures to clamp down on the trade of chelonians in the largest "pet market" in China (Gong et al., 2009).

Two articles discuss the failure to enact the draft PRC Animal Protection Law/Anti-Cruelty Law ( 中华人民共和国动物保护法/反虐待动物法) released in 2009. The draft law was ambitious in the large scope it proposed initially, imposing a duty of care on owners of economic (farm), pet, laboratory, and entertainment animals (Brown, 2018, p.198). However, the draft law's large scope led to significant political opposition. In the end, the draft law was watered down to only prohibit overt forms of cruelty, and still failed to be adopted by the Chinese legislature (Kerr \& Dan, 2015, p.76).

The failure of previous legislative efforts to deliver meaningful animal protection is attributed to several reasons. These include China's prioritizing of economic growth; competing interests pushing for the watering down of key provisions; as well as a failure to enact animal protection provisions beyond administrative regulations (Ibid., p.75-76). Moreover, there is a prevalent belief in Chinese society that China must first raise levels of human welfare before working towards raising levels of nonhuman animal welfare (Øyen, 2012, p.479) (Brown, 2018, p.198).

\subsubsection{Drivers of progress}

Two English articles discuss various animal advocacy successes in China's recent history, short of legal and policy changes. There has been a marked increase in the number of local celebrities and animal advocacy organizations speaking out in support of animal protection in recent years (Meng, 2012, p. 1150) as well as discussions surrounding the legal status of nonhuman animals, animal cruelty, and links between animal welfare and public health (Littlefair, 2012).

An interesting case study involves the Chinese pharmaceutical company Guizhentang (归真堂). Established in 2000, the company mainly produces and sells bear bile products. In 2012, there was significant backlash from local animal organizations after the company's plans to go public were announced, a reflection of the clash between the Chinese public's increasingly "ecocentric" animal protection views and the country's "anthropocentric" animal protection laws (Cui, 2012).

A major driver of pro-animal developments in recent years is international trade dynamics. In their efforts to boost Chinese exports of animal products, Chinese officials and farmers have paid more attention to animal welfare, due to animal welfare trade barriers erected by China's trading partners such as the European Union (Littlefair, 2012, p.228). Economic gains aside, other instrumental goals such as environmental and public health improvement have also influenced pro-animal developments (Tao, 2003). 


\subsection{Wild animals}

\section{Primary themes and sub-themes}

Through manual interpretation of the retrieved literature, articles relating to wild animals were identified and then categorized into various primary themes. For the Chinese articles, 5 primary themes were identified: law and policy, conservation, attitudes, and education (Table 5). A handful of articles retrieved addressed meta-issues surrounding the impact and influence of animal protection organizations in China. For the English literature, 6 primary themes were identified: conservation, habitat protection, law and policy, public attitudes, reserves, and education (Table 6).

Based on these primary themes, dozens of sub-themes were also identified. It is important to note that these classifications reflect the themes found in the retrieved articles, and do not necessarily reflect issues to do with wild animal suffering, which is the specific cause area Animal Ethics is focused on.

Table 5. Chinese wild animal articles: themes and sub-themes

\begin{tabular}{clc}
\hline Theme & \multicolumn{1}{c}{ Sub-theme } & Retrieved \\
\hline & General & 51 \\
& Welfare & 49 \\
& Trade and trafficking & 19 \\
& Endangered & 16 \\
& Criminal & 7 \\
& Rights & 6 \\
& Bears & 5 \\
& Breeding & 4 \\
& Compensation & 3 \\
& Damage & 3 \\
& Aquatic animals & 3 \\
& Ethics & 3 \\
& Transport & 2 \\
& Standardization & 2 \\
& Salamanders & 1 \\
& Ecological Civilization & 1 \\
& Sables & 1 \\
& Monkeys & 1 \\
& Invading species & 1 \\
& Fur & 1 \\
\hline & General & 23 \\
& Aquatic animals & 6 \\
& Deers & 5 \\
& Zoos & 2 \\
& Antelopes & 3 \\
& Fur & 3 \\
& & \\
& &
\end{tabular}




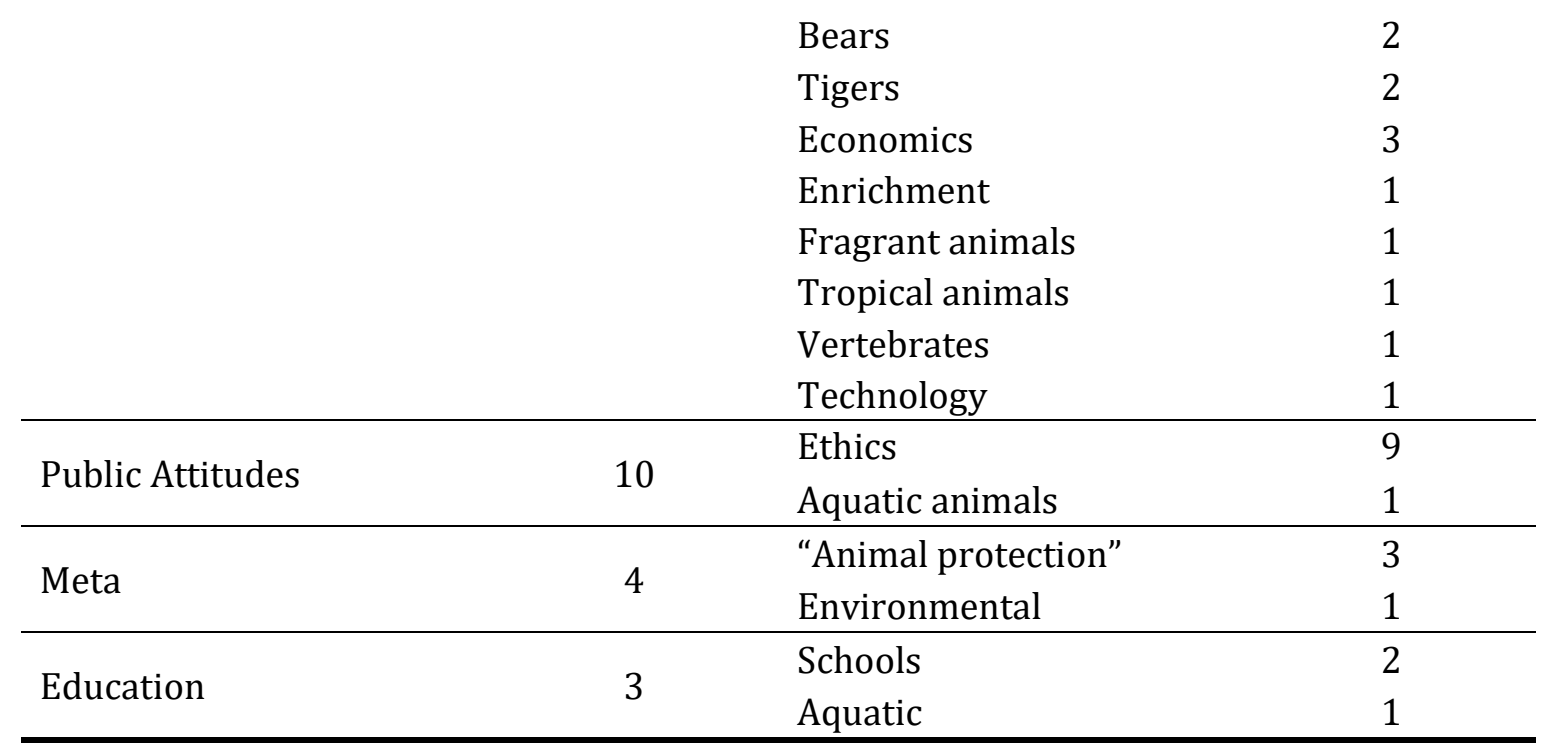


Table 6. English wild animal articles: themes and sub-themes

\begin{tabular}{|c|c|c|c|}
\hline Theme & Retrieved & Sub-theme & Retrieved \\
\hline \multirow{8}{*}{ Conservation } & \multirow{8}{*}{46} & Wild animals & 13 \\
\hline & & Pandas & 10 \\
\hline & & Tigers & 6 \\
\hline & & Snow leopards & 4 \\
\hline & & Aquatic animals & 3 \\
\hline & & Other animals & 4 \\
\hline & & Deers & 2 \\
\hline & & Rescued wild animals & 1 \\
\hline \multirow{4}{*}{ Habitat Protection } & \multirow{4}{*}{15} & Pandas & 7 \\
\hline & & Tigers & 3 \\
\hline & & Wild animals & 3 \\
\hline & & Elephants & 2 \\
\hline \multirow{5}{*}{ Law and Policy } & \multirow{5}{*}{10} & Trade and trafficking & 3 \\
\hline & & Wild animal consumption & 2 \\
\hline & & Legal protection & 2 \\
\hline & & Pandas & 2 \\
\hline & & Bibliography (index) & 1 \\
\hline \multirow{4}{*}{ Public Attitudes } & \multirow{4}{*}{8} & Wild animal consumption & 4 \\
\hline & & Local communities & 2 \\
\hline & & Tourism & 1 \\
\hline & & General & 1 \\
\hline \multirow{3}{*}{ Reserves } & \multirow{3}{*}{5} & Pandas & 4 \\
\hline & & Elephants & 1 \\
\hline & & Wild animals & 1 \\
\hline \multirow{3}{*}{ Education Programs } & \multirow{3}{*}{4} & Zoos & 2 \\
\hline & & Snub-nosed monkeys & 1 \\
\hline & & Student camp & 1 \\
\hline
\end{tabular}




\subsubsection{Law and policies}

\section{Chinese articles}

The Chinese literature on animal protection laws and policies in China displays a clear concern with the legislation of other countries, including those discussing wild animal-related laws and policies (179 articles). Most of the comparisons were used to highlight areas where China is lacking.

For example, China's highway engineers might take as inspiration the highway design in the Netherlands, which boasts highway systems that achieve a high level of protection for wild animals (Wang et al., 2019). The European country's highway systems reduce fragmentation of wild animal habitats by having passages for wild animals and amphibians to travel through. While the fragmentation of habitats can have overall negative and positive effects for animals (Hecht \& Allcock, 2020), the passages save the lives of many.

Wu (2012, p. 119) assesses China's criminal laws surrounding biodiversity protection, which are seen to be lacking compared with other countries that have "scientific and advanced characteristics" including Brazil, Canada, and France. China's list of wild animals under state priority conservation (国家重点保护野生动物名录) - promulgated on the back of the PRC Wildlife Protection Law (WPL) (中华人民共和国野生动物保护法) (1988) - is especially criticized for its limited scope. Criminal laws for animal protection should extend beyond wild animals to cover "ordinary" animals as well (Ibid., p.121).

It is worth noting that the author uses the term "animal resources" throughout the article. This is a theme in the Chinese literature, whereby conservationism rather than the wellbeing of individual animals seems to be the main focus of the articles. In total, 16 Chinese articles discuss wild animals of species considered endangered, almost half of these focusing on China being a party to the Convention on International Trade in Endangered Species of Wild Fauna and Flora (CITES), a conservation treaty and the first multilateral environmental treaty China ever joined.

\section{English articles}

The English literature on this topic (10 articles) are less analytical and more descriptive about the main wild animal protection laws and policies in China. The main laws discussed are the WPL, CITES, the PRC Criminal Law, and the Constitution itself.

Eight of those 10 articles discuss the WPL. The seminal law contains a framework for wild animals' domestication and industry usage, including ownership of wild animal resources, along with lists of protected wild animals (Cao, 2015) (Watters \& Xi, 2002). The law states that wild animals are owned by the state and provides criminal and administrative sanctions for those that illegally hunt or kill animals included in state protection lists (Ibid.).

Echoing similar sentiments in the literature on animals in general, the English literature on wild animals also evokes the clash between conservation policies and an anthropocentric interest in using wild animals as resources (Cao, 2015, p. 28). The WPL is one such example, as it is a human- 
centered law that focuses on the use of wild animals for human purposes (Sima \& O'Sullivan, 2016).

In the discussion surrounding CITES, there is recognition that the Chinese government has ramped up efforts to implement the treaty's requirements to combat wild animal smuggling (Chang, 2017). However, the treaty also has ongoing weaknesses in China, such as its anthropocentric approach, which fails to "recogniz[e] [animals'] intrinsic value as sentient lives" (Cao, 2016, p.275).

The PRC Criminal Law meanwhile, adopted in 1979, prohibits acts against certain speciallyprotected wild animals (Cao, 2016). "Wildlife crime" is considered a serious offense punishable with jail time. The crackdown on such crime has been bolstered in subsequent years by secondary measures such as an ivory trade ban (Cao, 2016) as well as the proposed animal protection draft law (Sima \& O’Sullivan, 2016). However, wildlife crimes continue to occur (Cao, 2016), partly due to inadequate international cooperation and enforcement (Mak \& Song, 2018).

Several articles from China's Constitution are relevant to the legal protection of certain wild animals (Feng, Liao \& Hu 2019). For example, Article 9 stipulates that natural resources (including rare animals) should be "rationally used" and damage to these resources is prohibited, while Article 26 requires the state to protect and improve the environment and to prevent pollution (Watters \& Xi, 2002, p.500). These provisions do not directly provide protection for animals, and nor do they cover all animals, but they do provide legal basis for protecting some animals.

\subsubsection{Conflation of conservation and wild animal protection}

\section{Chinese articles}

As touched on above, a running theme in the literature is the conflation of the protection of wild animals with environmentalist and conservationist concerns, even for articles that purport to deal with concern for animals. In this section, we focus on articles that best demonstrate this misunderstanding. Some of these articles offer additional insights into how environmentalist organizations have succeeded in China, providing useful takeaways for animal organizations.

Environmentalist NGOs account for only $1.5 \%$ of civil society organizations in China, but "their impact has surpassed civil organizations in other fields" (Wen, 2013, p.56). Applying social network theory to the "landmark" case study of the Tibetan antelope - a class one protected species under Chinese laws - it is suggested that various Chinese environmentalist NGOs have achieved success in protecting the antelope by leveraging the social networks of their founders (Ibid.).

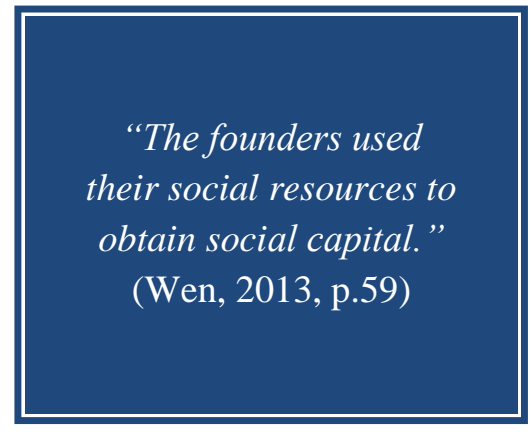

The two most famous local organizations in this space are Green River (绿色江河) and Friends of Nature (自然之友). The founders of both organizations 
were highly influential and respected. Yang Xin (楊欣), Green River's founder, had considerable stature in society due to his previous work on the protection of habitats along the Yangtze River. Liang Congjie (梁从诫), Friends of Nature's founder, was a member of the CPPCC National Committee, China's top political advisory body, as well as a descendant of a renowned family of intellectuals. "In China, having such social capital means being more easily recognized and supported by society, and having more authority in this field of work" (Wen, 2013, p.59).

A key responsibility of local environmentalist NGOs historically has been public outreach (Sun \& Xie, 2019). One of the most popular methods of doing so are publicity campaigns targeting busy public areas such as railway and subway stations, as well as airports. For example, the International Fund for Animal Welfare's (IFAW) anti-ivory trade publicity campaign has been particularly successful, having penetrated $75 \%$ of China's urban population and lowered the inclination of certain consumer groups to buy these products from $54 \%$ to $26 \%$ (Ibid., p.81).

Influencing government policy has only recently emerged as a key task of local NGOs doing work related to wild animals. Three channels are identified for doing this: submitting opinions and suggestions to the relevant government agencies; demanding the release of government information related to wild animals and pursuing administrative litigation against those agencies that refuse; and submitting reforms at the annual "Two Sessions" meeting in Beijing through legislators and CPPCC members who are sympathetic to the cause (Ibid., p.82).

The conflation of environmentalist or conservationist efforts and wild animal protection is clear when articles supposedly praising wild animal protection efforts defend anthropocentrism and criticize the legal protection of wild animals: "Existing social organizations pay more attention to the protection of wild animals and ignore or even oppose the rational use of wild animals, which can easily mislead the public into the misunderstanding of protecting wild animals for the sake of protecting wild animals" (Ibid., p.82). As discussed above, many Chinese articles refer to wild animals as "resources" rather than as sentient individuals.

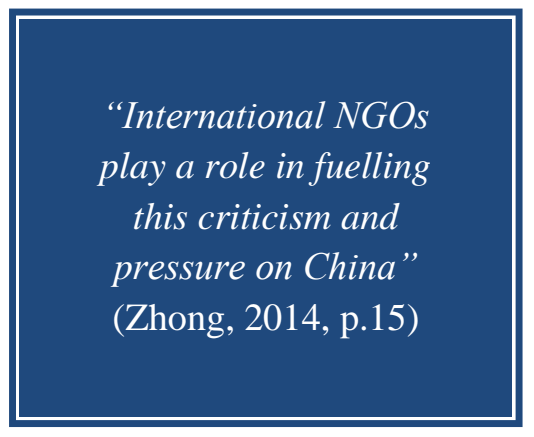

Another significant responsibility of local environmentalist NGOs is to liaise and connect with the international NGO community. However, there has been criticism of these NGOs, typically driven by nationalist sentiment, for allegedly failing to improve China's image overseas: “China's wild animal protection NGOs had a late start and a low starting point, while their foreign equivalents had an early start and a high starting point, and have penetrated into all aspects of China's wild animal protection space ..." (Zhong, 2014, p.14)

The article criticizes aspects of international NGOs activities in China, accusing them of compiling "one-sided information" about deficiencies in China's legal protection of animals, which is then used by foreign governments and companies to undermine China's international reputation and hinder the development of traditional Chinese medicine and other local industries. "The Western world has criticized and put pressure on my country by invoking so-called 'superpower responsibilities' such as fighting illegal wildlife trade, guaranteeing animal welfare, tackling 
climate change etc. Meanwhile, international NGOs play a role in fuelling this criticism and pressure on China." (Ibid., p.15)

Local environmentalist NGOs are an important part of the government's efforts to construct an "ecological civilization," therefore they should better understand what the concept means and align their activities with it. Crucially, they must always have the national interest in mind when they integrate into the international NGO landscape and guide the international community to fully understand the actual situation in China and respect China's cultural concepts and traditions (Ibid.).

The conflation of conservation and wild animal protection can also be found in 2 of the 3 Chinese articles retrieved relating to education. One article surveyed primary school students in six cities and conducted interviews with experts to probe the status of education about wild animal protection in China (Lu, 2016). It is claimed that the school students surveyed had a strong awareness of "wild animal protection" when what the article really means was conservationism, not the protection of individual animals, as it points to the schools' focus on promoting students' "ecological moral consciousness," for example. Similarly, another article about wild animal education is really about conservation and not wild animal protection per se, as it analyzes conservationist teaching in Hungary to pick out appropriate measures to improve China's conservation research and education (Bao \& Zhang, 2006).

\section{English articles}

Similar to the Chinese literature, the English literature also often demonstrates conflation of wild animal protection and conservation, even for articles supposedly to do with concern for animals.

Several articles discuss habitat fragmentation or loss especially for animals considered charismatic, such as pandas, Amur tigers, and Asian elephants, due to road construction and traffic (Zhang et al., 2015) (Chang, 2015) (Xu, 2009) (Wang et al., 2009); human settlements and cropland (Wang et al., 2016) (Xu et al., 2006) (Zhang \& Wang, 2003); deforestation (Liu et al., 2016) (Taylor \& Zisheng, 1988); and food scarcity (Luan et al., 2011). These articles often make suggestions for habitat protection planning, including enhancing forest management (Taylor, 1988) and improved planning tools (Kong et al., 2017). These discussions are mainly conservationist in nature and do not necessarily reflect a concern for the welfare of wild animals.

\subsubsection{Public attitudes towards wild animals}

\section{Chinese articles}

There were relatively few Chinese articles retrieved discussing public attitudes towards wild animals (10 articles). The few articles that do are not survey or poll reports, but rather general discussions of the fundamental local concepts underpinning attitudes towards wild animals.

Ancient Chinese ideas of animal rights are discussed, for example those relating to the killing of animals considered "pests." Traditional Chinese agronomy recognized that insects had the same right to exist in nature as other beings and therefore did not endorse their eradication the way 
farmers do today: "insects and humans should and can live in harmony" (Yan, 2005, p.85). Ensuring the survival rights of insects is not only beneficial to the insects, but also to humans, because of the value of biodiversity (note that this right to exist is framed in a collective manner, rather than for insects on an individual basis - a right to survival of a certain population is not the same as a right to live of a certain individual).

Many traditional Chinese concepts are referenced, albeit not in the context of concern for the interests of individual animals but for other considerations. For example, it is claimed that problems for humans caused by certain animals are fundamentally due to human beings rebelling against the "way of heaven" (天道). The "life force" of nature (氣) is disrupted by human activity. As such, humans should stop killing animals regarded as "pests," and in doing so prevent animalrelated problems from arising (Ibid.).

\section{English articles}

Eight English articles retrieved discuss Chinese public attitudes towards wild animals. More of the English articles are quantitative surveys and polls of Chinese attitudes, compared with the Chinese articles. All of these articles focused on Chinese people's conservationist attitudes rather than their attitudes towards the wellbeing of individual wild animals. Among other topics, some of the issues covered by these articles include wild animal consumption, attitudes among minority communities, and regional differences.

Being young (18-29 years of age), more educated (college and above) and a white-collar worker (monthly salary above USD \$650) were found to be the prominent characteristics of heavy wild animal consumers (Zhang \& Yin, 2014) (Zhang et al., 2008). The two studies, which produced comparable results, also found that conservationist attitudes in favor of wild animal protection had increased from $42.7 \%$ (data collected in 2004) to 52.7\% (data collected in 2012).

On the other hand, there is also evidence suggesting that youth and higher education correlates with lower wild animal consumption. Two articles surveyed public attitudes towards tiger consumption and conservation with 1,058 and 1,180 participants respectively (Liu et al., 2014) (Gratwicke et al., 2008). These surveys found lower levels of tiger consumption among younger and more educated consumers. The surveys found that both students and the general public were by and large supportive of a tiger trade ban.

It should be noted that a choice to consume or not to consume wild animals does not necessarily correlate with a concern for the suffering of wild animals. There may be other reasons, such as a priority for certain animals over others because of their conservation status. In the latest survey, $63 \%$ of participants indicated that tiger farming should be allowed to continue, mainly due to a desire for the continuation of the species (Liu et al., 2015, p. 369). This suggests that most respondents were driven not by concerns for the wellbeing of individual animals but rather by conservationist concerns in their responses.

Two surveys explored regional differences in public attitudes towards wild animals (Feng \& Zhang, 2014) (Zhang et al., 2008). They found a higher level of conservationist attitudes among respondents in Beijing and Shanghai, compared with other cities such as Guangzhou. The articles 
suggested that recent increases in conservationist attitudes in Beijing and Shanghai may be attributable to public awareness campaigns run during the 2008 Beijing Olympics and the 2010 Shanghai World Expo. Although an increase in conservationist attitudes does not necessarily mean people are caring more about the wellbeing of wild animals per se, it does suggest that the combined influence of major global events held in China and public awareness campaigns may be effective in improving public attitudes towards wild animals, potentially from a wild animal welfare perspective.

Two articles explored the attitudes of minority communities towards wild animals, both in Yunnan province (He et al., 2011) (Yang et al., 2010). Specifically, the Mosuo and Yi communities were found to have negative attitudes towards wolves, dholes and boars because these wild animals destroy their crops and kill animals they use as resources, which is hard to bear given these groups' poor economic circumstances (Ibid.). The article recommended the authorities compensate affected parties in order to stop local people from taking revenge on wild animals.

Religious belief, gender, and education were found to influence conservation attitudes among the Mosuo and Yi people. As both communities have traditional cultures generally supportive of respect for some wild animals, those who were more religious were found to have more positive attitudes towards these animals (Ibid., p.65). Beliefs include taboos surrounding eating and hurting certain types of wild animals. Pro-animal attitudes were also more prevalent amongst females in both communities and those with higher levels of education.

At a more fundamental level, the Chinese concept of harmony (和) - the idea of things having a structure and way to relating with each other - is key to understanding the Chinese humananimal relationship (Qingming et al., 2012). The concept ascribes aesthetic value to animals, which determines what position (位) each animal should be in in order to be in harmony with society (Ibid., p.29). Referring to the case study of Chinese tourists on Nanwan Monkey Island in Hainan province, where the main tourist activity is to come into close contact with monkeys, the article asks whether this tourist activity could help foster more positive attitudes towards monkeys and promote the idea of living in harmony with animals and nature. However, there are also significant drawbacks identified, including monkeys being fed unhealthy food by tourists.

\subsection{Animals used for food}

\subsubsection{Potential initiatives for improving the situation of animals used for food}

Eight English articles were retrieved relating to the welfare of animals farmed for human consumption, including discussions surrounding perceptions and attitudes towards these animals. Other key research themes include people's willingness to contribute financially to improve welfare levels for these animals. Several articles examined and proposed different ways of improving the current situation of animals used for food. This section is noteworthy because 
some of these methods may be relevant to the improvement of the situation of animals generally in China, not just animals used for food.

Three articles addressed people's willingness to pay (WTP) for improving animal welfare. In one study, $89.5 \%$ of 229 respondents supported paying more to improve the living conditions of animals (Zhao \& Wu, 2011), while $45.1 \%$ of 6,006 respondents in another study were reported to be "to some degree willing to [pay more]" (You et al., 2014). More broadly, $81.6 \%$ of the 6,006 respondents thought that animal welfare laws were necessary and $44 \%$ replied with negative comments towards factory rearing (Ibid.). Moreover, despite recognition that there are low levels of awareness of the welfare of animals used for food in China, 81\% of 229 respondents were willing to pay for products originating from "farm animal welfare" associated brands while 83\% believed that there should be laws to protect animals (Zhao \& Wu, 2011).

To increase awareness in Chinese society of the welfare of animals used for food, it is suggested that improved education is key (Yin et al., 2018) (Zhao \& Wu, 2011). For example, there should be more materials and content provided relating to animal welfare at all educational levels (Wei, 2012), as well as greater levels of international collaboration between lawmakers, academics, and NGOs (Meng et al., 2012).

Two articles discuss the meat industry's unsustainable growth and its effects on animal welfare (Tao, 2003) as well as public health and the environment (Li, 2009). This growth is reported to be largely state-supported through more than 3,000 policies such as favorable land distribution, loosened restrictions on production, and adoption of the "Western" intensive farming model. The negative effects of this development, such as worsened food safety, have fuelled public discontent (Ibid.).

\subsubsection{Dogs}

Several English articles discuss dog consumption in particular. Four articles discuss the history of the practice in China, touching upon some of the key historical factors that have shaped Chinese people's relationships with animals through the years. These discussions also highlight some key differences between Chinese and foreign perspectives on humans relationships with non-human animals, shedding light on how these differences can contribute to animosity between Chinese people and their critics.

One of the major reasons for dog consumption was widespread poverty in China in the $20^{\text {th }}$ century. Dog consumption was necessary as food was at a premium $(\mathrm{Wu}, 2002)$, for example during the Great Leap Forward period (Øyen, 2012). Even before the $20^{\text {th }}$ century, dogs were only kept and bred as pets by the richest segments of society during the dynastic periods (Hurley, 2016), while dogs were only work animals and a food source for the poorest (Brown 2018).

The popularity of dog meat festivals in China was found to be attributable to three main reasons: food safety concerns (people's preference for fresh meat, and being able to check the health of the animal before buying); non-discrimination of dogs and other animals traditionally used as food $(\mathrm{Wu}, 2002)$; and low awareness of sentience and animal welfare (Kerr \& Dan, 2015). However, 
the Chinese authorities have clamped down on dog consumption in recent years, in part due to international criticism (Brown, 2018).

Four articles claim that dog consumption is now restricted to small communities and rare occasions. A lack of official data on the industry's impact on the economy suggests a negligible impact (Li, Sun \& Yu 2017, p. 529), while dog meat was found to be mainly sold by small-scale local traders (Li, Sun \& Yu, 2017).

Five articles discuss how differences between China and foreign perspectives on animals have made dog consumption in China a controversial topic. Differences in the historical economic situations of China and other countries (Hurley, 2016) (Brown, 2018), as well as differences in which animals are viewed as food sources and which as pets (Kerr \& Dan, 2015) have contributed to a reductive understanding of China in the West (Wu, 2002), which can be viewed as an imposition of Western values (Hobson, 2007).

It is important therefore to recognize and present China's cultural context in campaigns tackling dog consumption and other animal campaigns (Øyen, 2012). On the other hand, the decline of dog consumption in China may also largely be due to growing domestic opposition rather than external criticism (Li, Sun \& Yu, 2017). As such, international animal advocacy groups supporting Chinese activists can do so confidently, as they are not imposing "Western" values but rather advocating universal values (Ibid.).

\subsection{Animals kept as companions}

\subsubsection{Economic growth and increase in keeping animals as companions}

Five English articles discuss the recent increase in the keeping of animals as companions in China (Gong et al., 2009). Various reasons are given for this development: China's economic growth, which has raised standards of living and disposable income; urbanization; new lifestyle trends ("individualization"); and changes in hobbies and habits.

China's economic growth in recent decades has ushered in a consumerist society, which is influencing people's daily lives more than Maoism and Confucianism and, similar to Western consumer-based individualism, ${ }^{4}$ it has "changed the standards for proper, civilized and good behavior" (Øyen, 2012, p.467). Middle-class lifestyle habits have become more dominant, such as the keeping of dogs and cats as companions, while also serving as status symbols (Brown, 2018).

Higher income levels have facilitated new lifestyles previously impossible (Hobson, 2007), including the keeping of animals as companions and bearing associated costs (Li, Sun \& Yu, 2017).

\footnotetext{
${ }^{4}$ Øyen (2012) points out that this was not accompanied by the development of a rights-based individualism like the one present to a large extent in the West
} 
This is most apparent in developed cities like Beijing (150,000 licensed dogs in 2003 to 900,000 in 2010) (Øyen, 2012. p.477).

\subsubsection{Growing awareness and public engagement}

Five English articles address the changing perceptions of animals kept as companions and increased awareness of these animals' welfare in Chinese society. Various reasons are given for this, including the increased propensity for animals kept as companions; growing influence of animal welfare organizations; strengthening civil activism; and increased media coverage.

As a result of greater numbers of animals being kept as companions, there has been a shift away from viewing certain animals purely instrumentally (Øyen, 2012). The practice of keeping these animals as companions has made "an increasing number of Chinese more sympathetic to the needs and welfare of animals" (Hobson, 2007, p.260), resulting in more humanistic and moralistic attitudes towards individual animals ( $\mathrm{Li}$, Sun \& Yu, 2017, p.529). In particular, millennials are more likely to develop compassion for animals as they enjoy better economic circumstances, which makes them more likely to keep animals as companions (Kerr \& Dan, 2015).

This shift in attitudes has also led to more media attention being paid to exposing incidences of animal cruelty. This has helped spark protests against cat abusers and dog meat festivals (Øyen, 2012). A new vocabulary and discourse of animal welfare has emerged, in which groups and individuals can articulate their animal-related concerns surrounding public institutions and policies (Hobson, 2007, p. 261). At the same time, animal welfare organizations have been empowered to make their demands heard, such as the Chinese Animal Protection Network's influential campaign against the consumption of cats and dogs (Ibid., Oyen, 2012, p.478).

\section{Discussion}

\subsection{Increasing concern for, and discussion about, animals}

The results indicate a significant increase in the literature with respect to animals in China, a positive indicator of growing interest in animals over time. However, this should not lead us to be excessively optimistic, as this increase is not necessarily due to a growth in concern for nonhuman animals. First, this increase could be driven by the fact that there has been a significant increase in animals used as resources in China, especially in factory farms. Second, as previous mentioned, there is a common confusion of the protection of wild animals, who are individuals with interests of their own, with the conservation of their species. Therefore, an increase in the literature with respect to animals might reflect growing conservationist concerns, but not necessarily concern for individual animals' wellbeing.

Nonetheless, it is clear that there have been growing debates between defenders and critics of speciesist viewpoints, as is the case in other parts of the world, even if the literature is still scarce. 


\subsection{Tapping into Chinese philosophical traditions}

A key takeaway from the results is that arguments supporting the moral consideration of animals that appeal to sentience, akin to similar arguments defended in Western philosophy, can be found in different Chinese philosophical traditions. Buddhism, Taoism and Confucianism are the traditions with the most potential, based on the amount of discussion they are given in both the English and Chinese literature. There is a general consensus that arguments rooted in these traditions may be more successful in shaping Chinese people's attitudes and behavior than those grounded in Western philosophy.

\subsection{Insufficient and inadequate legislation}

When it comes to China's laws and policies protecting animals, the results suggest that there are significant limitations to how effectively Chinese laws protect animals. Even though China does have laws and policies designed to protect animals, these are often conservationist in nature. There is also a problem of inadequate enforcement, which renders these laws and policies irrelevant. Moreover, these laws and policies are outnumbered by laws and policies that view animals as resources to be exploited. However, these deficiencies in China's legal regime for protecting animals are not unique to China. Even countries with relatively strong protection of animals are often criticized by animal advocates for having insufficient and inadequate legislation.

Fortunately, there seems to be several forces present that are changing the legislative situation in China. One of them is the external pressure for China to meet certain international standards for the treatment of nonhuman animals. Those standards, however, are not very high (see Animal Ethics 2016). Another factor is the growing interest towards the moral consideration of animals among the Chinese population. This was observed in the literature especially for young people, highly educated people, and people keeping animals as companions.

\subsection{Wild animals still not recognized as individuals}

Many of the takeaways from the literature about animals generally also apply to wild animals specifically. The most salient theme identified in the literature review is the substantial conflation of concern for wild animals and conservation of animal species. This is something that also happens in other parts of the world, although perhaps to a lesser extent.

\subsection{An opportunity: helping charismatic animals}

A significant proportion of retrieved articles focuses on advocacy efforts and ways of improving the situation of certain animals deemed charismatic in China, such as pandas. As such, wild animal suffering interventions aiming to reduce the suffering of charismatic animals may be well received among both the Chinese public and authorities. However, a risk of this approach is that 
it will exacerbate the conflation of concern for wild animals and conservationism. Nonetheless, the approach could be a way in which the public can start to become familiar with the idea of wild animal suffering. Moreover, it may help challenge another confusion along the same lines: the confusion between animals' wellbeing and their survival. Interventions of this kind could help to develop methods of research focused on the wellbeing of animals, rather than their mere survival.

\subsection{Foundation-building through public education}

The literature also gives us a useful insight when it comes to the consumption of certain wild animals from a conservationist standpoint. There are different attitudes towards such consumption, and those groups of people who have been the target of educational efforts against these practices have a noticeably lower level of acceptance than those who have not. There is good reason to believe that similar results can be attained through educational efforts focused not on conservation ideals but instead on concern for welfare.

Moreover, based on the successes of some environmental organizations in China, animal organizations should recognize the importance of building social capital in support of their efforts to influence government policy and gain public support for their causes.

\subsection{General takeaways from the situation of animals used for food}

Attitudes and policies relating to animals used for food mirror attitudes and policies towards animals generally. There have been some efforts to change the situation, such as educational efforts, which have had some success, but initiatives to change policy and legislation have often failed.

As in the case of wild animals, many concerns surrounding animals used for food relate not to the interests of animals but other concerns, such as the impact of factory farms on human beings and associated environmental problems. This is not different from what happens in other countries, although it seems that the extent to which these alternative concerns dominate discussions in the literature on China is greater.

\subsection{The case of dogs used as food}

A special case is the use of dogs for food. While no distinction should in principle be made between dogs and other animals used for the same purpose, foreign speciesist attitudes favoring dogs over other animals have had an impact in China, such as pressure on China to reduce dog consumption. This international pressure has succeeded somewhat in reducing dog consumption; however, it has also been met with pushback from Chinese authors, who say that this pressure is unfair. 


\subsection{Takeaways from the situation of animals kept as companions}

In the case of animals kept as companions, we saw again the problem of the lack of enforcement of the laws protecting them. More positively however, due to social and economic changes in recent decades, the keeping of animals as companions has grown significantly in China, which in turn has led to greater awareness of the interests that animals have. This has made Chinese society more likely to react negatively towards at least some forms of animal abuse.

\section{Limitations}

There are many important questions that are crucial for a correct appraisal of the issues that have been considered here but have not been addressed by the available literature. This means that while a literature review like this can shed some light on these issues, it leaves some other relevant problems unresolved. These include the ways in which organizations can best approach their work in China, what their relationship with Chinese authorities should be, the actual way in which animal advocacy is developing in China, and the ways in which concern for wild animals may be best advocated for in China.

These issues should be researched further using different methods such as interviews with key agents, scholars, and animal advocates in the field.

\section{Conclusions}

The main findings of this study can be summarized as the following:

- While concern for nonhuman animals in Chinese society has grown (especially among those living with animals as companions), it is still insufficient. As a result, many practices harmful towards animals remain unchallenged and civil society seems unable to have a strong influence over authorities to make significant changes in legislation protecting animals.

- In part due to the previous point, laws in China protecting animals remain underdeveloped compared to other countries (even though in other countries with more developed laws, the legal protections are still unacceptable from the viewpoint of taking animals' interests seriously).

- Building a social basis for the defence of animals seems to be imperative for this cause to be successful. This seems to be feasible if we consider the evolution of consideration for animals in China discussed above, as well as the possibility of education making a difference in that respect. 
- China's own philosophical traditions could provide the grounding for change without having to appeal to arguments underpinned by foreign philosophical traditions.

- In the case of wild animals, there is not yet concern about them as individuals, so their protection is viewed as largely synonymous with the conservation of their species. This is not very different from what happens in other countries at present.

- Interventions to help some wild animals regarded as particularly charismatic by the Chinese public may be a promising way to animate this field with a message focused on individuals, instead of species.

These points may improve approaches to animal advocacy work in China generally, as well as for wild animals in particular.

\section{Acknowledgements}

We want to express our gratitude to Animal Charity Evaluators, which funded this work through its Animal Advocacy Research Fund.

\section{References}

Animal Ethics (2016) Animal Exploitation, Animal Ethics, https://www.animal-ethics.org/animalexploitation-introduction

Askue, L., Heimlich, J., Yu, J. P., Wang, X. H., \& Lakly, S. (2009). "Measuring a Professional Conservation Education Training Program for Zoos and Wildlife Parks in China." Zoo biology, 28(5), 447-461. doi:10.1002/zoo.20210

Bao, Weidong 鲍伟东., Zhang, Shuli 张书理. (2006). “Xiongyali yu woguo yesheng dongwu baohu jiaoxue zhi bijiao 匈牙利与我国野生动物保护教学之比较 [Comparison of Wildlife Conservation Teaching in Hungary and My Country]”. Forestry Education in China 中国林业 教育 (02), 70-72.

Bexell, S. M., Luo, L., Hu, Y., Maple, T. L., McManamon, R., Zhang, A., . . . Tian, Y. (2004). "Conservation education initiatives in China: A collaborative project among zoo Atlanta, chengdu zoo, and chengdu research base of giant panda breeding." In Giant Pandas: Biology and Conservation (pp. 264-267).

Brown, H. (2018). Yulin lychee and dog meat festival: A shift in focus. In Tourism Experiences and Animal Consumption: Contested Values, Morality and Ethics (pp. 193-207).

Cao, Wenbin 曹文斌., \& Chen, Baojian 陈宝健. (2009) "Xifang donwu jiefang lun yu zhongguo fojiao hu sheng guan bijiao yanjiu 西方动物解放论与中国佛教护生观比较研究 [Comparative Investigation of Western Animal Liberation Theory and Chinese Buddhist 
Viewpoints of Protecting Beings]”. Journal of Zunyi Normal College 遵义师范学院学报 11(03), 5-9.

Cao, D. (2015). Animals in China. doi:10.1057/9781137408020

Cao, D. (2016). "Wildlife Crimes and Legal Protection of Wildlife in China." In D. Cao \& S. White (Eds.), Animal Law and Welfare - International Perspectives (Vol. 53, pp. 263-278).

Ceng, Hanliang 曾瀚良.(2017) “Qian xi zhongguo rujia, daojia lunli si xiang dui yesheng dongwu baohu de yingxiang 浅析中国儒家、道家伦理思想对野生动物保护的影响 [Analysis of the Influence of Chinese Confucian and Taoist Ethics on the Protection of Wild Animals]". Northern Literature 北方文学 (20), 142-143.

Chang, J. (2017). "China's Legal Response to Trafficking in Wild Animals: The Relationship between International Treaties and Chinese Law." AJIL Unbound, 111, 408-412. doi:10.1017/aju.2017.104

Chen, Benhan 陈本寒., \& Zhou, Ping 周平. (2002). "Dongwu falu di wei zhi tantao-—jian xi woguo minshi lifa dui dongwu de ying you dingwei 动物法律地位之探讨一一兼析我国民 事立法对动物的应有定位 [A Research on the Legal Status of Animals]”. China Legal Science 中国法学(06), 65-74.

Cui, Li 崔莉. (2012). “Zhongguo dongwu baohu de lifa benwei ying fou tiaozheng 中国动物保护的 立法本位应否调整 [Should China's Animal Protection Legislation Standard be Adjusted]”. Science News 科学新闻 (03), 38-41.

Feng, L., Liao, W., \& Hu, J. (2019). “Towards a more sustainable human-animal relationship: The legal protection of wildlife in China." Sustainability (Switzerland), 11(11). doi:10.3390/su11113112

Gong, S.-P., Chow, A. T., Fong, J. J., \& Shi, H.-T. (2009). The chelonian trade in the largest pet market in China: scale, scope and impact on turtle conservation. Oryx, 43(2), 213-216. doi:10.1017/S0030605308000902

Guo, Hui 郭辉., Li, Bing 李冰. (2009). “Wanshan woguo dongwu baohu lifa jian zhiyi “dongwu zhuti lun” 完善我国动物保护立法兼质疑“动物主体论”[Doubts about “The Dominant Position of Animals"]”. Journal of Hebei Software Institute 河北软件职业技术学院学报11(01), 7780.

Gratwicke, B., Mills, J., Dutton, A., Gabriel, G., Long, B., Seidensticker, J., ... Tregenza, T. (2008). "Attitudes Toward Consumption and Conservation of Tigers in China." PloS one, 3(7), 1. doi:10.1371/journal.pone.0002544

Han, X. (2011). "The forest stand structures in northeastern China; their potential effects on the suitability of forests for animals, plants, and other values; and the possible relationships to Amur tiger (Panthera tigris altaica) conservation."

He, Q., Wu, Z., Zhou, W., \& Dong, R. (2011). "Perception and attitudes of local communities towards wild elephant-related problems and conservation in Xishuangbanna, southwestern China." Chinese Geographical Science, 21(5), 629-636. doi:10.1007/s11769-011-0499-4 
Hecht, L., \& Allcock, M. (2020). "Potential effects of habitat fragmentation on wild animal welfare.” EcoEvoRxiv https://doi.org/10.32942/osf.io/hb7nm

Hobson, K. (2007). Political animals? On animals as subjects in an enlarged political geography. Political Geography, 26(3), 250-267. doi:10.1016/j.polgeo.2006.10.010

Hurley, S. (2016). Human-canine relationships in China. In Companion Animals in Everyday Life: Situating Human-Animal Engagement within Cultures (pp. 129-144).

Kerr, A., \& Dan, Y. (2015). Tradition as Precedent: Articulating Animal Law Reform in China. Journal of Animal and Natural Resource Law, 11, 71-85.

Kong, L., Xu, W., Zhang, L., Gong, M., Xiao, Y., \& Ouyang, Z. (2017). "Habitat conservation redlines for the giant pandas in China." Biological Conservation, 210, 83-88. doi:10.1016/j.biocon.2016.03.028

Li, P. J. (2009). Exponential Growth, Animal Welfare, Environmental and Food Safety Impact: The Case of China's Livestock Production. Journal of Agricultural and Environmental Ethics, 22(3), 217-240. doi:http://dx.doi.org/10.1007/s10806-008-9140-7

Li, Liang 李亮. (2012) “Xifang dongwu baohu lunli ji qi dui zhongguo de yingxiang 西方动物保护 伦理及其对中国的影响 [Western Animal Protection Ethics and its Influence on China]". Journal of Nanjing Forestry University (Humanities and Social Sciences Edition) 南京林业大 学学报(人文社会科学版) 12(02), 12-14.

Li, P. J., \& Davey, G. (2013). "Culture, Reform Politics, and Future Directions: A Review of China's Animal Protection Challenge." Society \& Animals, 21(1), 34-53. doi:10.1163/1568530612341264

Li, P. J., Sun, J., \& Yu, D. (2017). Dog "Meat" Consumption in China. Society \& animals : social scientific studies of the human experience of other animals., 25(6), 513-532. doi:10.1163/15685306-12341471

Littlefair, P. (2012). Why China is waking up to animal welfare. In Animals, Ethics and Trade: The Challenge of Animal Sentience (pp. 225-237).

Liu, Z., Jiang, Z., Li, C., Fang, H., Ping, X., Luo, Z., .. Z Zeng, Y. (2015). "Public attitude toward tiger farming and tiger conservation in Beijing, China." Animal conservation, 18(4), 367-376. doi:10.1111/acv.12181

Liu, P., Wen, H., Lin, L., Liu, J., \& Zhang, L. (2016). "Habitat evaluation for Asian elephants (Elephas maximus) in Lincang: Conservation planning for an extremely small population of elephants in China." Biological Conservation, 198, 113-121. doi:10.1016/j.biocon.2016.04.005

Lu, Linlin 卢琳琳. (2016). “Woguo bufen diqu xiaoxuesheng yesheng dongwu baohu xianzhuang diaocha ji duice fenxi 我国部分地区小学生野生动物保护现状调查及对策分析 [Investigation on Wildlife Protection Status and Countermeasure of Elementary School Students in Parts of China]". Chinese Journal of Wildlife 野生动物学报 37(02), 166-171.

Luan, X. F., Qu, Y., Li, D. Q., Liu, S. R., Wang, X. L., Wu, B., \& Zhu, C. Q. (2011). Habitat evaluation of wild Amur tiger (Panthera tigris altaica) and conservation priority setting in north-eastern 
China. Journal of Environmental Management, 92(1), 31-42. doi:10.1016/j.jenvman.2010.08.001

Mak, G. J. K., \& Song, W. (2018). "Transnational norms and governing illegal wildlife trade in China and Japan: elephant ivory and related products under CITES." Cambridge Review of International Affairs, 31(5), 373-391. doi:10.1080/09557571.2018.1530636

Meng, X. X., Hamer, R., Meng, Q. H., Wang, P., Meng, F. L., Li, H. L., . . Zhou, Y. J. (2012). Animal Welfare Development in China. Science, 338(6111), 1150-1151. doi:10.1126/science.338.6111.1150

Min, Hao 闵浩., \& Gao, Xiaohua 高小华. (2014). “Zhongguo ru dao liang jia de dongwu baohu sixiang di dang dai yiyi 中国儒道两家的动物保护思想的当代意义 [The Contemporary Significance of the Animal Protection Thoughts of Confucianism and Taoism in China]." Legal System and Society 法制与社会 (31), 173-174.

Ning, Jing 宁静., \& Wang, Wei 王威. (2006). “Woguo xuyao fan nuedai dongwu fa 我国需要反虐待 动物法 [My Country Needs Anti-Animal Cruelty Laws]”. Gansu Agricultural 甘肃农业(12), 274.

Niu, K. F., Tan, C. L., Cui, D. Y., Chen, S., Shi, L., Balletto, E., ... Yang, Y. Q. (2015). “Creating Wildlife Exploration Stories to Promote Conservation of the Endangered Guizhou Snub-Nosed Monkey in Fanjingshan National Nature Reserve, China." Folia Primatologica, 86(4), 330330.

Oyen, S. A. (2012). The Chinese animal: From food to pet. In Climate Change and Sustainable Development: Ethical Perspectives on Land Use and Food Production (pp. 475-480).

Qingming, C., Honggang, X., \& Wall, G. (2012). "A Cultural Perspective on Wildlife Tourism in China.” Tourism Recreation Research, 37(1), 27-36. doi:10.1080/02508281.2012.11081685

Sinclair, M., \& Phillips, C. (2018). "Key Tenets of Operational Success in International Animal Welfare Initiatives.” Animals, 8(6), 92. doi:10.3390/ani8060092

Singer, P. (1976). Animal Liberation : a New Ethics for our Treatment of Animals. London: Cape.

Sima, Y., \& O'Sullivan, S. (2016). "Chinese animal protection laws and the globalisation of welfare norms". International Journal of Law in Context, 12(1), 1-23. doi:10.1017/S1744552315000348

Smith, A., \& Yan, X. (2013). Mammals of China, 7-7. doi:10.1515/9781400846887.7a

Su, B., Martens, P., \& Enders-Slegers, M.-J. (2018). A neglected predictor of environmental damage: The ecological paw print and carbon emissions of food consumption by companion dogs and cats in China. Journal of cleaner production, 194, 1-11. doi:http://dx.doi.org/10.1016/j.jclepro.2018.05.113

Tao, B. (2003). A stitch in time: Addressing the environmental, health, and animal welfare effects of China's expanding meat industry. Georgetown International Environmental Law Review, 15(2), 321-357. 
Taylor, A. H., \& Zisheng, Q. (1988). "Structure and composition of selectively cut and uncut AbiesTsuga forest in Wolong Natural Reserve and implications for panda conservation in China." Biological Conservation, 47(2), 83-108.

Wang, X., Xu, W., \& Ouyang, Z. (2009). "Integrating population size analysis into habitat suitability assessment: implications for giant panda conservation in the Minshan Mountains, China." Ecological Research, 24(5), 1101-1109. doi:10.1007/s11284-009-0589-2

Wang, T., Feng, L., Mou, P., Wu, J., Smith, J. L., Xiao, W., ... Ge, J. (2016). Amur tigers and leopards returning to China: direct evidence and a landscape conservation plan. Landscape Ecology, 31(3), 491-503. doi:10.1007/s10980-015-0278-1

Wang, Yun 王云., Guan, Lei 关否., Yang, Yangang 杨艳刚., Kong, Yaping 孔亚平. (2019). “Helan gonglu jianshe yesheng dongwu baohu chenggong jingyan ji dui 荷兰公路建设野生动物保 护成功经验及对 [The Successful Experience of Wildlife Protection in Dutch Highway Construction and its Inspiration to China]". Science \& Technology of Communications 吉林 交通科技 (03), 17-20.

Watters, L., \& Xi, W. (2002). "The Protection of Wildlife and Endangered Species in China." Georgetown International Environmental Law Review, 14(3), 489.

Wei, S. (2012). Animal welfare legislation in China: Public understanding and education. In Animals, Ethics and Trade: The Challenge of Animal Sentience (pp. 101-110).

Wen, Yihua 文艺花. (2013). "Yi shehui wangluo lilun shijiao fenxi zhongguo huanbao zuzhi de shehui yingxiang li: yi baohu zang lingyang yundong wei li 以社会网络理论视角分析中国 环保组织的社会影响力 - - 以保护藏羚羊运动为例 [An Analysis on Social Influence of Chinese Environmental Protection Organization from the View of Social Network Theory: Protection the Tibetan Antelope as a Case]". Journal of Kunming Metallurgy College 明冶金 高等专科学校学报 29(6), 56-59. doi:http://dx.doi.org/10.3969/j.issn.10090479.2013.06.013

Worldometer (2020). "Real time world statistics." Retrieved from https://www.worldometers.info/

Wu, F. H. (2002). The Best "Chink" Food: Dog Eating and the Dilemma of Diversity. Gastronomica, 2(2), 38-45. doi:http://dx.doi.org/10.1525/gfc.2002.2.2.38

Wu, Xianping 吴献萍. (2012). “Bijiao fa shi yu xia woguo dongwu ziyuan baohu xingshi lifa de wanshan 比较法视域下我国动物资源保护刑事立法的完善 [Perfecting the Criminal Law on the Protection of Animal Resources from the Perspective of Comparative Law]". Journal of Central South University of Forestry \& Technology (Social Sciences) 中南林业科技大学学 报(社会科学版) 6(02), 119-123.

Xiang, Linnan 相林男 (2009). “Cong geguo lifa shili kan woguo fan nuedai dongwu lifa Zhong dui nuedai de dingyi 从各国立法实例看我国反虐待动物立法中对“虐待”的定义 [Viewing the Definition of "Abuse" in our Country's Anti-Animal Cruelty Legislation from the Legislative Examples of Various Countries]". Knowledge Economy 知识经济 (02), 22+30. 
Xiao, J., Xu, W. H., Kang, D. W., \& Li, J. Q. (2011). “Nature reserve group planning for conservation of giant pandas in North Minshan, China." Journal for Nature Conservation, 19(4), 209-214. doi:10.1016/j.jnc.2011.01.003

Xu, Yingchun 许迎春., Tian, Yiwen 田义文., Zhu, Baojian 朱保建., \& Wang, Linyue 王琳玥. (2006). “Lun woguo fan nuedai dongwu de lifa de biyao xing yu kexing xing 论我国反虐待动物的 立法的必要性与可行性 [On the Necessity and Feasibility of Anti-Animal Cruelty Legislation in my Country]". Truth Seeking 求实(S3), 103-104.

Xu, W., Ouyang, Z., Viña, A., Zheng, H., Liu, J., \& Xiao, Y. (2006). “Designing a conservation plan for protecting the habitat for giant pandas in the Qionglai mountain range, China." Diversity and Distributions, 12(5), 610-619. doi:10.1111/j.1366-9516.2006.00236.x

Xu, W., Wang, X., Ouyang, Z., Zhang, J., Li, Z., Xiao, Y., \& Zheng, H. (2009). “Conservation of giant panda habitat in South Minshan, China, after the May 2008 earthquake." Frontiers in Ecology and the Environment, 7(7), 353-358. doi:10.1890/080192

Yan, X. (2005). Conservation strategies of the Giant Panda in China. Chinese Journal of Zoology, $40(5), 57-60$

Yan, Huoqi 严火其. (2005). “Dongwu quanli lun de yi zhong gudai xingshi - zhongguo chuantong de haichong fangzhi lilun he jishu 动物权利论的一种古代形式一一中国传统的害虫防治理 论和技术 [An Ancient Form of Animal Rights Theory-The Theory and Technology of Pest Controlling in Ancient China]" Journal of Nanjing University of Science and Technology (Social Sciences Edition) 南京理工大学学报(社会科学版) (02), 85-87.

Yang, N., Zhang, E., \& Chen, M. (2010). "Attitudes towards wild animal conservation: A comparative study of the Yi and Mosuo in China." International Journal of Biodiversity Science, Ecosystem Services and Management, 6(1-2), 61-67. doi:10.1080/21513732.2010.509630

Yin, G., Yu, L., Quan, D., Zhang, Y., Ding, W., Liu, Y., \& Guan, L. (2018). Effects of Life Background on Chinese College Students' Cognition about Animal Welfare. NeuroQuantology, 16(6). doi:http://dx.doi.org/10.14704/nq.2018.16.6.1605

You, X., Li, Y., Zhang, M., Huoqi, Y., \& Zhao, R. (2014). A Survey of Chinese Citizens' Perceptions on Farm Animal Welfare. PLoS One, 9(10). doi:http://dx.doi.org/10.1371/journal.pone.0109177

Yu, Yetong 于也童. (2015). “Lun zhongguo “fan nuedai dongwu fa” chutai de biyao xing 论中国《 反虐待动物法》出台的必要性 [On the Necessity of Promulgating China's "Anti-Animal Cruelty Law"]". Journal of Liaoning Administrators College of Police and Justice 辽宁公安司法管理干部学 院学报(02), 1-4.

Zhang, L., \& Wang, N. (2003). An initial study on habitat conservation of Asian elephant (Elephas maximus), with a focus on human elephant conflict in Simao, China. Biological Conservation, 112(3), 453-459. doi:10.1016/S0006-3207(02)00335-X 
Zhang, L., Hua, N., \& Sun, S. (2008). "Wildlife trade, consumption and conservation awareness in southwest China." Biodiversity and conservation, 17(6), 1493-1516. doi:10.1007/s10531008-9358-8

Zhang, L., \& Yin, F. (2014). "Wildlife consumption and conservation awareness in China: a long way to go." Biodiversity \& Conservation, 23(9), 2371-2381. doi:10.1007/s10531-0140708-4

Zhang, L., Dong, T., Xu, W. H., \& Ouyang, Z. Y. (2015). “Assessment of habitat fragmentation caused by traffic networks and identifying key affected areas to facilitate rare wildlife conservation in China." Wildlife research, 42(3), 266-279. doi:10.1071/wr14124

Zhao, Yingjie 赵英杰., \& Nie, Guodong 聂国东. (2007). “Shandai shengling - yingguo dongwu fuli fa jieshao ji dui woguo de qishi 善待生灵一英国动物福利法介绍及对我国的启示 [Be Kind to Creatures-Introduction to British Animal Welfare Law and its Enlightenment for my Country]”. The Science Education Article Collects 科教文汇(上旬刊) (05), 158.

Zhao, Y., \& Wu, S. (2011). Willingness to Pay: Animal Welfare and Related Influencing Factors in China. Journal of Applied Animal Welfare Science, 14(2), 150-161. doi:10.1080/10888705.2011.551627

Zhong, Yi 钟义. (2014). “Woguo yesheng dongwu fei zhengfu baohu zuzhi mianlin de tiaozhan yu duice 我国野生动物非政府保护组织面临的挑战与对策 [Challenges \& Countermeasures of the NGO on Wildlife Conservation of China]". State Academy of Forestry Administration Journal 国家林业局管理干部学院学报 14(03), 13-16. 